\title{
VIDEO ANALYSIS "BISA KEMBALI NORMAL? OBAT COVID-19 SUDAH DITEMUKAN!!" FROM COMMUNICATION PHILOSOPHY PERSPECTIVE
}

\section{Karem Rouby Islam}

Diponegoro University, Semarang, Jawa Tengah, Indonesia

Email: islamkaremrouby@gmail.com

\begin{abstract}
The video entitled "Bisa Kembali Normal? Obat Covid-19 Sudah Ditemukan!!" is a video containing an interview between Anji and Hadi Pranoto who claims that he has succeeded in finding a Covid-19 antibody drug, that can prevent and cure patients who have been infected with the coronavirus in just 2-3 days. Many experts also doubt Hadi Pranoto's statements in the video. With the many reactions from the public regarding the video, Cyber Indonesia General President reported Anji and Hadi in August 2020 of violating laws in Indonesia. This article uses a Descriptive Analytic Method. This Article aims to explain the concepts of Human Understanding and Communicating Effectivity in Communication Philosophy. The Concept of Human Understanding is the information provided will form an understanding in society, and the Concept of Communication Effectivity is information/ideas that are conveyed that will effectively change people's behavior. In this case, it was understood that Hady Pranoto had found an anti-COVID-19 drug that could prevent and cure. Then from the information provided, it will result in those who agree to believe what Hadi Pranoto said, will buy the antibody-drug, but those who disagree such as the experts will deny the information provided by Hadi Pranoto, which can also be considered as hoax news. This effect will affect the behavior of people watching the video, which leads to community disorders.
\end{abstract}

Keywords: Philosophy of Communication; Hoax; COVID-19; Indonesia.

Coresponden Author

Email: islamkaremrouby@gmail.com Article with open access under license

\section{Introduction}

Erdian Aji Prihartanto or known as "Anji" is one of the Indonesian musicians who is known for his song "Bersama Bintang". The former vocalist of the band Drive, who is now active as content creator on the YouTube platform since February 23, 2014 (Dunia MANJI - YouTube, 2021), is now in the spotlight of the wider community especially in Indonesia, after the video entitled "Bisa Kembali Normal? Obat Covid-19 Sudah Ditemukan!!" was published on his YouTube channel "dunia MANJI" on 31 July 2020. 
This article offers a new view of how communication occurs, and how we as humans understand something from our everyday communication. By using a philosophical view of the practice of communication in the public space, (In this case, public space is YouTube). Especially if a hoax comes from a public figure, it will attract the attention of Indonesians as well as the government, because it is a sensitive subject. This article aims to explain the concepts of human understanding and communication effectiveness in the philosophy of communication.

The video, entitled "Bisa Kembali Normal? Obat Covid-19 Sudah Ditemukan!!" is a video containing an interview between Anji and Hadi Pranoto who claims that he has succeeded in finding a COVID-19 antibody drug that can prevent and cure patients who have been infected with the COVID-19 in just 2-3 days. The video, which lasted about 30 minutes, suddenly became a topic of conversation among the wider community especially in Indonesia, because the Indonesian people still had doubts about the COVID19 antibody drug and also the information presented by Hadi Pranoto (Citradi Tirta, 2020).

This public doubt has basis, because many experts (especially in microbiology field) also doubt Hadi Pranoto's statements in the video, such as the Indonesian Doctors Association (IDI) which states that Hadi Pranoto is not a member of the IDI, the Jakarta Athletes Wisma Emergency Hospital which denies that they are using drugs COVID-19 antibodies from Hadi Pranoto, the Food and Drug Supervisory Agency (BPOM) who confirmed that they had never given permission to distribute herbal medicines claiming to be able to treat COVID-19 disease until now, IPB University denied that Hadi Pranoto who claimed found COVID-19 antibody drug is not a doctoral graduate alumni from IPB University, and Professor Ali Ghufron Mukti as Chair of the Consortium for Research and Innovation for Handling COVID-19 of the Ministry of Research and Technology explained that before drugs are distributed to the public, they must go through several stages of clinical trials and if the drug is registered with BPOM it must also be clear the classification (TvOne, 2020).

Since there are many reactions from the public because they are worried about the correctness of the information conveyed in the video entitled "Bisa Kembali Normal? Obat Covid-19 Sudah Ditemukan!!" General Chairman of Cyber Indonesia, Muannas Alaidid reported Anji and Hadi Pranoto to The Greater Jakarta Metropolitan Region of the Indonesian National Police or known as Polda Metro Jaya on 3 August 2020 for violations of Article 28 Paragraph (1) and Article 15A of Law of the Republic of Indonesia Number 19 of 2016 or Articles 11 and 15 of Law of the Republic of Indonesia Number 1 of 1946 concerning Regulations Criminal law. With this report, Polda Metro Jaya, represented by the Head of Public Relations of Polda Metro Jaya, Kombes Pol Yusri Yunus will summon Anji and Hadi Pranoto to be questioned, and since there are a lot of reactions from society Anji also apologizes to the public (Al Farisi, 2020).

In order to understand this case. First, we must look at the definition of philosophy itself. Al-Farabi (870-950BC) stated that philosophy is the science of the natural manifestation or knowledge about physical nature (ilmu pengetahuan tentang alam maujud) (Sunarto, 2020). 
In terms of communication science, this case showed that communication takes form as a transmission model, or it's commonly called Transmission Communication Model Theory. This theory by John Locke explained that communication is not only a ritual of togetherness but has become a transmission that also transmits ideas of thought. Ideas transmitted from the messenger to the recipient cannot be completely received by the recipient due to an internal process that occurs in the recipient's mind. This process makes the meaning of what is conveyed different because the meaning is still a simple idea, which is then processed into a complex idea (Utomo, E, 2019).

From the perspective of our daily communication sequence, there is always a pattern of information flow from one person to another. And this pattern was seen by Harold Lasswell as a development from Shannon's theory. Communication theory according to Harold Lasswell is a theory that is required to answer the question about "Who Says What in Which Channel to Whom with What Effect". "Who" is the source, "Says What" is the message to be conveyed, "In Which Channel" is the Channel/Media that used, "To Whom" is to the receiver, "With What Effect" is the result/the effect (Abazari \& Brojeni, 2017).

From Shannon's theory, we could understand that a communication flow between humans has two primary goals, human understanding, and communication effectivity. These two concepts will determine how humans communicate with each other by using every channel possible. Human understanding concept is closely related to John Locke's theory of transmission communication model since it relates to internal processes from within the human mind itself. Whether the idea is perfect or not transmitted from the messenger to the receiver depends on the internal processes that occur in the mind of the recipient and this will form the understanding of the communication that has been conveyed. while communication effectivity as by Shannon has identified a noise in communication which was later developed by Warren Weaver by identifying three levels of communication problems, as follows: (Anggriana, 2017).

1) Level A: how accurately can the symbol of communication be transmitted? (Accuracy Problem);

2) Level B: how precisely do the transmitted symbol convey the desired meaning? (Semantic Problem);

3) Level C: how effectively does the received meaning affect conduct in desired way? (Effectivity Problem).

In the concept of communication effectivity, it is entered at level $\mathrm{C}$ which means that effective communication occurs when the meaning conveyed by the source can be accepted and affects the recipient's behavior as desired by the source. At level $\mathrm{C}$ this is also supported by the theory of cybernetics communication by Norbert Wiener (Johnson, 2015) who added that communication is also a control so that the recipient of the message is able to capture the meaning of the message conveyed as expected by the source. 


\section{Methods}

This paper belongs to descriptive research based on the analytical method. It is the appropriate method to describe and analyze this case according to communication theories and models (Allen, 2017). The researcher collected data from primary and secondary sources represented in books, scientific journals and websites. In the analytical framework, the researcher used an explanation of the concepts of Human Understanding and Communication Effectivity in Communication Philosophy.

\section{Results and Discussion}

In the video entitled "Bisa Kembali Normal? Obat Covid-19 Sudah Ditemukan!!" published on dunia MANJI YouTube channel can be viewed from various theories and concepts in communication science. The video is an interview video between Anji and Hadi Pranoto, which occurs a communication. According to Janis \& Kelly explains that communication is a process carried out by communicators to convey stimulus (usually in the form of words) with the aim of changing or shaping the behavior of others (White, 2015).

The concept of human understanding is closely related to John Locke's transmission communication model theory, which communication is not only a ritual of togetherness but has become a transmission that also transmits ideas of thought (KARMAN, 2014). Ideas transmitted from the messenger to the recipient cannot be completely received by the recipient due to an internal process that occurs in the recipient's mind. This process makes the meaning of what is conveyed different because the meaning is still a simple idea, which is then processed into a complex idea. The video entitled "Bisa Kembali Normal? Obat Covid-19 Sudah Ditemukan!!" published on dunia MANJI YouTube channel is also a transmitting of ideas from Hadi Pranoto who was interviewed by Anji. Probably these ideas are also not necessarily true, but the ideas conveyed will be seen and heard by video viewers. The audience of the video will process their thoughts internally about what has been conveyed by Hadi Pranoto, which then will be a complex idea for the audience of the video and it could be that the meaning conveyed could be different. After this process, the audience has an understanding of the information delivered by Hadi Pranoto (human understanding).

In the concept of human understanding, whether the idea is perfect or not transmitted from the messenger/source to the recipient depends on the internal process that occurs in the recipient's mind and this will shape the understanding of the communication that has been conveyed. But what has been conveyed by Hadi Pranoto in the video entitled "Bisa Kembali Normal? Obat Covid-19 Sudah Ditemukan!!" which was published on dunia MANJI YouTube channel, made many experts many experts argue that the invention research by Hadi Pranoto are not clear, yet need to be further explained. In fact, many experts disprove Hadi Pranoto's opinion in the video. Here are some of Hadi Pranoto's claims that have been disprove by several experts: 
Hadi Pranoto said that the medicine is a COVID-19 antibody, while Agung Dwi Widodo is a Lecturer in Microbiology at Universitas Airlangga said that antibodies are substances produced inside the body; (KOMPASTV, 2020).

Hadi Pranoto said that the virus will die at temperatures above 350 degrees Celsius and there is a COVID-19 test with digital technology for only IDR 10,000, while Herawati Sudoyo is Deputy Head of the Eijkman Institute said that the corona virus will be damaged at 56 degrees Celsius and until now there is no digital technology for the corona test at only Rp.10,000; (KOMPASTV, 2020).

Hadi Pranoto said that his medicine invention medicinal are the development of antibody drugs for SARS, MERS, Flu Burung and later for COVID-19 the only difference is the dosage, while Ahmad Rusdan Utomo, $\mathrm{PhD}$ is a molecular biologist said the difference between SARS and COVID- 19 is very far away and not about dosage because these are different variants of the virus (Narasi, 2020).

Since there many opinions of Hadi Pranoto that have been denied by several experts, it have made the research conducted by Hadi Pranoto doubtful that they have use the correct standards. So that the results of Hadi Pranoto's research, namely the COVID-19 antibody drug, are still in doubt. Even on several occasions as a guest speaker, Hadi Pranoto was inconsistent, such as in the video interview with Anji who said that he had found antibody drugs. Then when he became a speaker at KompasTV or TVONE, he only called it herbal medicine (TvOne, 2020). Based on this, in terms of the concept of human understanding, what has been conveyed by Hadi Pranoto is false information. Therefore, the audience's understanding of the video is also false understanding. This can happen because the messenger, in this case Hadi Pranoto, wants to influence the audience according to what he wants, for example: Hadi Pranoto wants to be known as a person which credited with finding the COVID-19 antibody drug, Hadi Pranoto wants that the people will buy the medicine that he made, or other desires/interest. Thus, Hadi Pranoto said that the wrong information regarding the antibody drug on the MANJI YouTube channel and surely there will be a consequence, which it can be related to theory of communication by Harold Lasswell.

Communication theory according to Harold Lasswell is a theory that is required to answer the question about "Who Says What in Which Channel to Whom with What Effect". The video entitled "Bisa Kembali Normal? Obat Covid-19 Sudah Ditemukan!!" published on dunia MANJI YouTube channel contains false information conveyed by Hadi Pranoto and as a result many experts have denied this information and this information from Hadi Pranoto has also caused public unrest. The false information conveyed by Hadi Pranoto can also be included in the concept of Communication Effectivity.

The concept of communication effectivity explains that effective communication occurs when the meaning conveyed by the source is accepted and affects the behavior of the recipient as desired by the source. In the video entitled "Bisa Kembali Normal? Obat Covid-19 Sudah Ditemukan!!" published on dunia MANJI YouTube channel provides false information that could be considered hoax information. This effect can affects the 
behavior of people watching the video, causing unrest for the people, which lead for General Chairman of Cyber Indonesia, Muannas Alaidid reported Anji and Hadi Pranoto to The Greater Jakarta Metropolitan Region of the Indonesian National Police or known as Polda Metro Jaya on 3 August 2020 for violations of Article 28 Paragraph (1) and Article 15A of Law of the Republic of Indonesia Number 19 of 2016 or Articles 11 and 15 of Law of the Republic of Indonesia Number 1 of 1946 concerning Regulations Criminal law, as well as a video entitled "Bisa Kembali Normal? Obat Covid-19 Sudah Ditemukan!!" published dunia MANJI YouTube channel has been removed by YouTube for violating the YouTube Community Guidelines. Therefore, so that public unrest does not continue until further, Hadi Pranoto should also be responsible for proving clearly (maujud) that the results of his research have been clinically tested and have passed the correct standard of research procedures to the society, and also tit can prevent and heal humans from COVID-19. Which also this has something related with the definition of philosophy according to Al-Farabi.

According to Al-Farabi (870-950 BC), philosophy is the science of the natural manifestation or knowledge about physical nature (ilmu pengetahuan tentang alam maujud). It should have been before Hadi Pranoto published to the public, his invention that could prevent and cure humans of COVID-19. Hadi Pranoto is also responsible for clearly proving (maujud) to the public that the invention can indeed be used to prevent and cure humans of COVID-19, especially since the drug has been sold. Hadi Pranoto is also responsible for proving clearly (maujud) that the results of his research have been clinically tested and have passed the correct standard of research procedures. Moreover, this case talks about science, which means that there must be clear evidence. Science itself must also be proven empirically. This proof can only be obtained through real in-depth observations, experiments, studies, and research (Anggara, 2020).

\section{Conclusion}

During the COVID-19 pandemic, most of the activities are limited, and this has an impact on almost all sectors, such as the economic sector, the health sector, the social sector, and the education sector. The impact of COVID-19 has also affected the behavior of society. Therefore, information related to COVID-19 is a sensitive issue, so the effect of providing misinformation can directly impact public unrest.

The emergence of the YouTube platform is an advancement for the media because everyone can provide information for free and even get money. On YouTube, everyone can provide information or ideas of their thoughts to others, which is related to model transmission communication theory. Because there is a transmission of ideas from the informer/source to the recipient, it will form an understanding of these ideas and this is known as human understanding. The source provides ideas or information on the YouTube platform to others/recipients, and there will be consequences that arise and this has entered into communication theory by Harold Lasswell. Then it is about the consequences, then one of the consequences is that the information/ideas conveyed will effectively change people's behavior (communication effectivity). Until this stage, there 
is a need for clear and real proof (definition of philosophy according to Al-Farabi (870$950 \mathrm{BC})$ ) so that the information provided is correct and does not cause public unrest.

Anji is here as a public figure that helps Hadi Pranoto using his YouTube channel to provide information to the public. It is not impossible the public will believe what Hadi Pranoto said, even though the information has not been verified/true yet. Therefore it should be before Anji makes someone a speaker who will give information to the public especially on a sensitive topic such as COVID-19. Anji must do background checking on the speaker. Moreover, Hadi Pranoto admits that he is a researcher or scientist, which usually requires a clear and real track record of research and publication. This track record is very important in scientific terms so that the person understands what is being discussed. Also, the public must be critical and do not easily believe in information that is not verified/true yet. 
Video Analysis "Bisa Kembali Normal? Obat Covid-19 Sudah Ditemukan!!" From The Perspective of Communication Philosophy

\section{BIBLIOGRAPHY}

Abazari, Z., \& Brojeni, M. (2017). The role of Harold Lasswell Communication Theory in Librarianship and Information Science. International Academic Journal of Humanities, 4(1), 187-199. www.iaiest.com

Al Farisi, B. (2020). Kontroversi Anji karena Video Wawancara dengan Hadi Pranoto, Dilaporkan ke Polisi dan Berujung Minta Maaf Halaman all - Kompas.com. https://www.kompas.com/hype/read/2020/08/06/071718866/kontroversi-anjikarena-video-wawancara-dengan-hadi-pranoto-dilaporkan-ke?page=all

Allen, M. (2017). The sage encyclopedia of communication research methods (Vols. 14). Thousand Oaks, CA: SAGE Publications, Inc doi: 10.4135/9781483381411

Anggara, D. (2020). 5 Prinsip dan Karakter Sains yang Harus Kamu Ketahui, Apa Saja? https://www.idntimes.com/science/discovery/dahli-anggara/prinsip-dan-karaktersains-c1c $2 / 5$

Anggriana, E. (2017). Model, Implementasi Shannon, Komunikasi Penyebaran, Weaver Melalui Kartu, Informasi Sehat, Indonesia Bantuan, Penerima Di, Iuran Kis-pbi Donggala, Kabupaten. Social Humanity: Jurnal Ilmu Sosial Dan Humaniora, 1(Desember), 38-45.

Citradi Tirta. (2020, March). Viral Anji-Hadi Pranoto Soal Temuan Obat Corona, Ini Faktanya. CNBC Indonesia. https://www.cnbcindonesia.com/tech/2020080311593 6-37-177077/viral-anji-hadi-pranoto-soal-temuan-obat-corona-ini-faktanya

dunia MANJI - YouTube. (2021). https://www.youtube.com/c/DuniaManji/about

Johnson, C. (2015). "French" cybernetics. French Studies, 69(1), 60-78. https://doi.org/10.1093/fs/knu229

Karman. (2014). Media Sosial: Antara Kebebasan Dan Eksploitasi Social Media: Between Freedom and Exploitation. Jurnal Studi Komunikasi Dan Media, 18(1), 75-88.

KOMPASTV. (2020). 5 Klaim Hadi Dipatahkan Oleh Pakar, Ini Selengkapnya YouTube. https://www.youtube.com/watch?v=NGgzIjGkSZg

Narasi. (2020). Reaksi Ahli Biologi Molekuler yang Asli Nonton Video Diskusi Anji dan Hadi Pranoto | Buka Mata - YouTube.

Sunarto. (2020). Pengantar Filsafat dan Etika Komunikasi. PPt/Pengantar Filsafat dan Etika Komunikasi/Komstrat/Mikom Undip/Semarang, Indonesia.

TvOne, T. S. (2020). Adu Argumen! IDI vs Hadi Pranoto Terkait Klaim Obat Herbal Anti Corona|AKIP - YouTube. https://www.youtube.com/watch?v=if42gicLcmo 
Karem Rouby Islam

Utomo, E, P. (2019). Review Buku Philosophy Of Communication Garry Radford. Universitas Diponegoro, January. https://doi.org/10.13140/RG.2.2.13327.23203

White, M. (2015). Communication and Persuasion. American Sociological Review, 19(3), 355-357. http://www.jstor.org/stable/2087772 